\section{After birth}

$\mathrm{N}_{\mathrm{o}}^{\circ}$ ovember 6. My niece is nine years old today.

My mind slips back to the day of her birth, the hours spent waiting restlessly with my mother at one end of our local community hospital maternity ward. I remember how it was: feeling somewhat out of place, an interloper, intimately involved yet ultimately useless. An odd shift from my usual role as family physician checking on patients, examining squirming newborns, wading through committee meetings, grabbing the occasional corridor consultation. I am a family member, simply. My sister, attended to by one of my colleagues, is the centre of concern.

We wait.

The labour seems inexorably long. At last, the tension breaks. A familiar sound severs the taut air, carrying

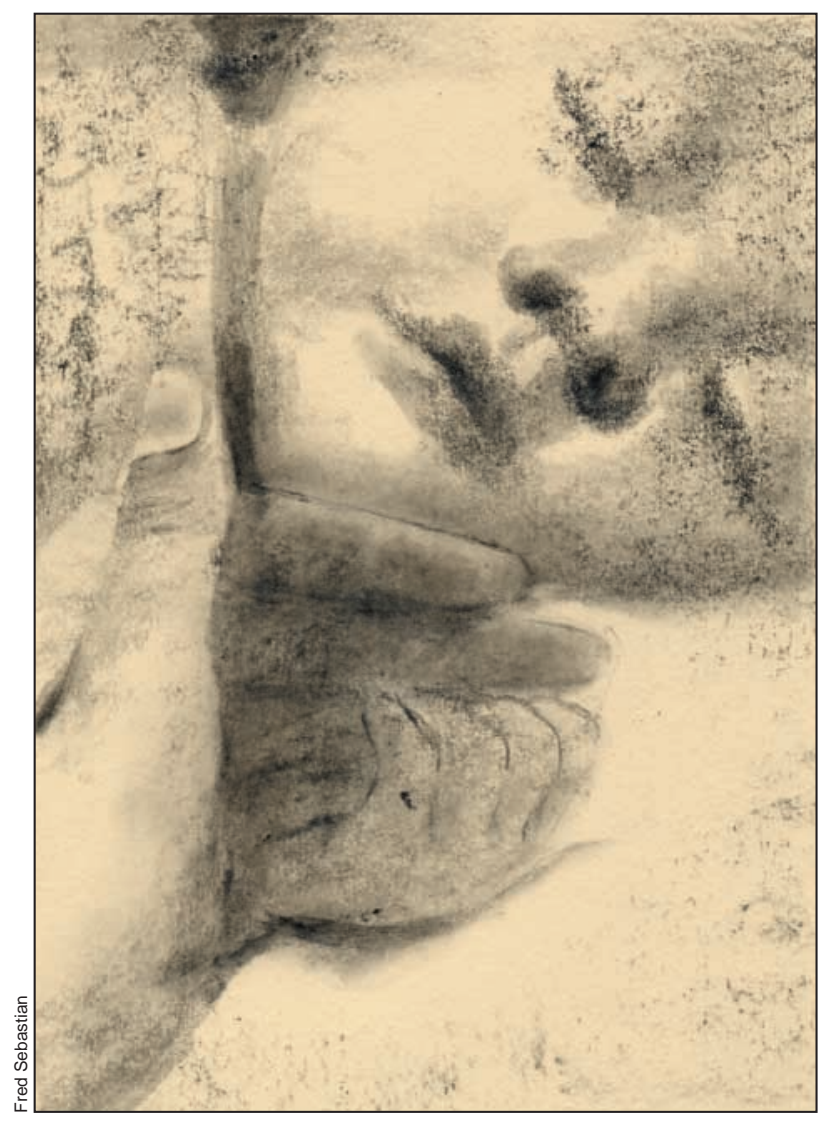

clearly down the hall. The plaintive wail of a newborn baby, hiccupping her protest at being dislodged from her placental nest. The sound brings relief, tears, laughter.

But even in this moment of joy, my mind re-enters an earlier time, engraved in memory, a day when I prayed for the baby not to cry.

I see myself years ago: a young family medicine resident on a threemonth obstetrical rotation at a large community hospital. My medical school training has ill-prepared me for the sheer volume and complexity of cases: hundreds of deliveries becoming a continuous blur, periodically studded with Technicolor images in sharp relief. Shoulder dystocia. Stillbirth. Chromosomal anomaly. The oldest first-time mother in her forties; the youngest, coincidentally on the same day, merely thirteen, a child having a child. And then, the patient I will always remember.

I am told she has been admitted in early labour, having had no prenatal care whatsoever. I head toward her room, puzzled. Lack of prenatal care is an unusual presentation in this urban centre, bustling with industry and ringed with sprawling suburbs. Whatever I might have anticipated, it is not this calm, articulate young woman with long ash-blonde hair and grave eyes. She is already the mother of a small boy. With simplicity and self-possession she tells me her story: how she became a single mother in her teens and dropped out of school. How she raised her son by herself on mother's allowance. How her son was now starting preschool, how she was finally free to take part-time classes, to complete high school, to get a job, and maybe eventually go to college. Her life was beginning again, her feet were almost under her, her options opening up. Until the night she met with the boy's father to discuss support. She described how she had "slipped up," vulnerable as she was to any offer of comfort. How she had hidden herself away, telling no-one - not even the father - that she was pregnant. How she had feared any pressure to have an abortion - something she could not contemplate - and so avoided medical care in the early months, having somehow convinced herself that no doctor would ever understand or respect her decision. By now accustomed to isolation and hardship, her trust so battered, she expected obstacles at every turn, certain that she would have to battle everyone to maintain her chosen course. She is less able to explain her reasons for staying away in the later stages. By then perhaps she felt a certain power in her self-sufficiency, cherishing every moment of the pregnancy, keeping it for herself, alone. For she wanted this child, this unexpected creation; she badly wanted to keep the owner of the little feet that pressed and kicked against her thin ribs. But she mustn't lose her chance, her son's chance; she mustn't gratify her desire and lose everything else. The only way she sees a future for her first child, and herself, is to give this baby up, to turn it over to anonymous hands, like Moses in the bulrushes.

She seems strangely calm, in contrast to the struggling knot of protest I feel rising in my chest. Surely there must be other options ... surely there is time to reconsider. 
No, she tells me. She has made her choice.

Her eyes falter, but her voice is steady, her words firm.

We call the social worker, then Children's Aid.

Her time comes. I am called to the delivery room. The baby emerges rapidly, forcefully, tearing at his mother's tender flesh. I barely have one glove on before the head is crowning, and soon the tiny body is tumbling out, so eager to enter the world, so unaware of all that awaits. The familiar heartbeat that has surrounded and sustained him all these many months is growing distant. Unlike his brother, he will not be returned and held close to it.

A beautiful boy, I long to say, but I must not. She has begged me not to.

She cries softly, her head turned aside.

Don't tell me what it is - don't show it to me - I won't be able to give it up I have to do this. I bave to.

The baby cries - tentatively at first, then in great lusty gulps. His mournful wails - Hush, child - echo though the unresponsive room, through heavy air thick with shame and loss. Both mother and child unappeased, unappeasable.

The baby is swaddled hastily, tenderly, then spirited out of the room to unknown waiting arms.

I silently sew up the visible ragged wound. It closes neatly, firmly. I can do nothing to mend the greater one.

$$
\text { *** }
$$

My niece cries, is held to my sister's breast for long draughts of comfort before being brought out to meet her family. She curled herself tightly into a ball, unperturbed, her fists waving vaguely. Her eyes close contentedly, security enveloping her as snugly as her pink flannel blanket.

I am haunted by the birth-pains that unfolded in that other time with such rending difference. I can still see a heartbroken woman with long ashblonde hair and hear a baby's cries receding down an endless corridor. And I continue to wonder, what has been the life of the one sacrificed? Of the other, whose future was bought at such a cost? And what of the one who chose?

What would it take to make such a choice?

I hold my niece close.

\section{Beverly J. Goodwin}

Consulting Psychiatrist

Lanark County Mental Health

Associate Medical Staff

Brockville Psychiatric Hospital

Brockville, Ont.

\section{Better off in a bubble}

A resident on our team has just paged me. I'm in emerg, she says. I'm alAready doing an admission, but there's another one here. Do you want to do it?

Sure, I say. I'll be right down.

Great, she says. I don't know much about it, but I think it's a boy with SCID.

SCID? I think. Oh God. Is he in a bubble or something? It's a long, slow walk down to the emergency department. I flip through my pocket reference, trying to learn something about immunodeficiency.

I exhale with relief when I arrive and look over the emerg sheet. SCAN, it says, not SCID. Except, what the heck is SCAN? I ask someone.

Oh, the emerg doc says, that's Suspected Child Abuse or Neglect.

That's much worse, I think. Can I have the kid in the bubble back?

A rag. That's what his mother's boyfriend has been stuffing in his mouth. To keep him quiet. Charming, I think. He's got a hematoma the size of a strawberry crowding his tiny mouth. He's miserable.

Things happen fast. He's admitted. He's fed through a tube in his nose. He gets better. He's apprehended. He gets a foster parent.

I go to see him just before he's discharged. Usually he's glad to see me, but I interrupt his eating and he's cranky.

Don't let anybody push you around, I tell him. Push back. I show him how to make a fist. I show him how to punch me in the jaw. He's six months old. He's going out there, where everything is so much bigger than he is.

Maybe he'd be better off in a bubble, I think.

Paul Moorehead

Pediatrics Resident

Memorial University of Newfoundland

St. John's, Nfld. 